\title{
Modeling Idiopathic Pulmonary Fibrosis in Humanized Severe Combined Immunodeficient Mice
}

\author{
David M. Habiel, Milena S. Espindola, Ana L. Coelho, and Cory M. Hogaboam
}

From the Women's Guild Lung Institute, Department of Medicine, Cedars-Sinai Medical Center, Los Angeles, California

\author{
Accepted for publication \\ December 28, 2017. \\ Address correspondence to \\ David M. Habiel, Ph.D., or \\ Cory M. Hogaboam, Ph.D., \\ Cedars-Sinai Medical Center, \\ 127 S. San Vicente Blvd., \\ AHSP A9404, Los Angeles, \\ CA 90048. E-mail: david. \\ habiel@cshs.org or \\ cory.hogaboam@cshs.org.
}

\begin{abstract}
Idiopathic pulmonary fibrosis (IPF) is a fibrotic lung disease of unknown etiopathogenesis with limited therapeutic options. IPF is characterized by an abundance of fibroblasts and loss of epithelial progenitors, which cumulates in unrelenting fibrotic lung remodeling and loss of normal oxygenation. IPF has been challenging to model in rodents; nonetheless, mouse models of lung fibrosis provide clues as to the natural progression of lung injury and remodeling, but many have not been useful in predicting efficacy of therapeutics in clinical IPF. We provide a detailed methodologic description of various iterations of humanized mouse models, initiated by the i.v. injection of cells from IPF lung biopsy or explants specimens into severe combined immunodeficiency (SCID)/beige or nonobese diabetic SCID $\gamma$ mice. Unlike cells from normal lung samples, IPF cells promote persistent, nonresolving lung remodeling in SCID mice. Finally, we provide examples and discuss potential advantages and pitfalls of humanspecific targeting approaches in a humanized SCID model of pulmonary fibrosis. (Am J Pathol 2018, 188: 891-903; https://doi.org/10.1016/j.ajpath.2017.12.020)
\end{abstract}

Despite the advent of approved pharmacologic interventions, idiopathic pulmonary fibrosis (IPF) remains one the most challenging interstitial lung diseases to manage clinically. ${ }^{1}$ This lung-localized disease is characterized histologically by the presence of usual interstitial pneumonia and specifically by the presence of fibroblastic foci, which are believed to be the site of active tissue remodeling. Recently, 2 new therapeutics, pirfenidone $^{2}$ and nintedanib, ${ }^{3}$ were approved for the treatment of IPF. However, these therapeutics have been observed to slow rather than stop the progression of the disease, with pirfenidone extending the mean lifespan of these patients by approximately 2.5 years. ${ }^{4}$ The fibrotic triggers in IPF are unknown, but it is speculated that persistent lung injury leads to alveolar epithelial cell injury and death and subsequent aberrant repair mechanism(s) ablates the alveolus. ${ }^{5}$ It is also hypothesized that the concomitant loss and/or dysfunction of epithelial progenitor cells might lead to aberrant proliferation, differentiation, and/or activation of fibroblasts, thereby contributing to the observed pathologic remodeling. ${ }^{6-10}$ Because of the checkered history of immunosuppressants in the treatment of IPF, the immune system has been largely abandoned as a key component in the pathogenesis of this disease. ${ }^{11}$ However, recent data suggest that interactions between the host innate immune system and the lung microbiome might influence progression-free survival in patients with IPF. ${ }^{12,13}$

Because of the idiopathic nature of this disease, several epidemiologic studies have examined links between lifestyle and environmental contaminants in the development of IPF, with potential correlations to smoking ${ }^{14}$ and industrial and occupational pollutants. ${ }^{15-18}$ However, none of these studies successfully pinpointed a consistent causative agent(s) in this

\footnotetext{
Supported by Cedars Sinai Medical Center (D.M.H. and C.M.H.), University of Michigan (C.M.H.), NIH grants R01 HL123899 (C.M.H.) and T32-HL007517-30 (D.M.H.), AdAlta (C.M.H.), Janssen (C.M.H.), NeoPharm (C.M.H.), Roche/Genentech (C.M.H.), AstraZeneca/MedImmune (C.M.H.), and Novartis (C.M.H.).

Disclosures: C.M.H. received research funding and reagents for the development of nonobese diabetic severe combined immunodeficiency $\gamma$ modeling approaches and therapeutic testing from the following: AdAlta, Janssen, NeoPharm, Roche/Genentech, AstraZeneca/MedImmune, and Novartis. Imclone provided reagents for therapeutic testing.
} 
disease, thus making it difficult to model IPF. Nonetheless, several rodent models of lung fibrosis have been developed to study the natural progression and regression of fibrosis, with the bleomycin model of acute lung injury and fibrosis being the most commonly used model. In this model, mice receive one $^{19-21}$ or multiple doses of intratracheal bleomycin, ${ }^{22}$ leading to acute epithelial injury and inflammation, followed by fibrotic lung remodeling. Other models include asbestos-,${ }^{23}$ silica-,${ }^{24}$ or fluorescein isothiocyanate-mediated lung injury and fibrosis ${ }^{25}$; radiation-induced fibrosis ${ }^{26,27}$; lung-specific IL- $13,{ }^{28} \mathrm{IL}-1 \beta,{ }^{29}$ tumor necrosis factor- $\alpha,{ }^{30}$ transforming growth factor- $\beta{ }^{31}$ or transforming growth factor- $\alpha^{32,33}$ overexpression; or humanized immunodeficient severe combined immunodeficiency (SCID)/beige (bg) mouse models ${ }^{34-37}$ of pulmonary fibrosis, all of which induce interstitial lung remodeling in rodents. ${ }^{38}$ Furthermore, advances in mouse genetic tools have led to the evolution of these models for the assessment of profibrotic pathways in pulmonary fibrosis; however, to date, there is no clear consensus about the best animal model(s) to use for the assessment of therapeutic efficacy in IPF. In addition, many of the mouse-centric animal models cannot be used to assess human-specific therapeutics. To this end, a large research effort is under way to develop experimental models for IPF, which are amendable to human-specific therapeutic assessment and that better predict efficacy of various therapeutics in ameliorating and/or halting the progressive lung remodeling in patients with IPF.

In this report, we provide detailed methods for several iterations of humanized mouse models of pulmonary fibrosis, where IPF nonimmune and immune cells engraft and drive a persistent and nonresolving lung remodeling process. This report is meant to describe methods regarding the use of humanized models of IPF to assess humanspecific pathways and therapeutics in vivo. In addition to the methods used, we provide examples of the assessment of potential antifibrotic therapeutics in vivo and some potential pitfalls and alternative approaches when assessing therapeutics that may differentially modulate immune and nonimmune cells.

\section{Materials and Methods}

\section{Cells and Cell Culture Conditions}

IPF diagnostic surgical lung biopsy samples were obtained as previously described. ${ }^{36}$ IPF lung fibroblasts were generated by mechanically dissociating IPF lung biopsy specimens or explants into sterile tissue culture plates. The demographic characteristics of the patients with IPF from whom cells were obtained and used are given in Supplemental Table S1. After mechanical dissociation, tissues were passed through a $25-\mathrm{mL}$ pipette 10 times in Dulbecco's modified Eagle's medium (Lonza, Basel, Switzerland) plus 15\% fetal bovine serum (Atlas Biologicals, Inc., Fort Collins, CO), $100 \mathrm{IU}$ of penicillin, $100 \mu \mathrm{g} / \mathrm{mL}$ of streptomycin (Mediatech, Manassas, VA), $292 \mu \mathrm{g} / \mathrm{mL}$ of L-glutamine (Mediatech), and $100 \mu \mathrm{g} / \mathrm{mL}$ of Primocin (InvivoGen, San Diego, CA) (complete medium). Cells were cultured at $37^{\circ} \mathrm{C}$ and $10 \% \mathrm{CO}_{2}$; medium was changed twice a week by careful removal of the liquid and retaining the minced tissues. This process was repeated for 1 to 2 weeks, until stromal colonies were apparent, after which fibroblast colonies were trypsinized and passaged. After four to five passages, fibroblast purity was confirmed using flow cytometry and/or real-time quantitative PCR analysis for CD45, EpCAM, and CD31. Fibroblasts were then cultured in complete medium; fresh medium was added to the fibroblasts every 2 to 3 days, and the cells were passaged when they were $70 \%$ to $90 \%$ confluent.

\section{Isolation of Fresh IPF Explant Cells}

Normal and IPF lung explants were placed into sterile PBS, washed, and transferred into fresh PBS. Tissue was minced and spun at $600 \times g$ for 5 minutes. Supernatants were collected with the PBS used to wash the explanted lungs (lung wash). The top layer of the pellet enriched in mechanically dissociated cells and red blood cells (RBCs) were strained through a $70-\mu \mathrm{m}$ strainer, with the strainer washed several times with Dulbecco's phosphate-buffered saline to separate cells from the minced tissues. This procedure was repeated until the RBCs and dissociated cells were removed from the minced tissue pellet. The dissociated cells were mixed with the lung wash and spun down at $400 \times g$ for 5 minutes. The RBCs were lyzed using RBC lysis buffer (Biolegend, San Diego, CA), and cells were then counted and viably frozen down using CryoStor CS10 freezing medium (STEMCELL Technologies, Vancouver, Canada). For in vivo experiments, cells were rapidly thawed, washed in serum-free medium, and intravenously injected into nonobese diabetic (NOD) SCID $I L 2 R \gamma^{-/-}$(NSG) mice as described below.

\section{Mice}

Pathogen-free SCID-beige (SCID/bg) and NSG mice 6 to 8 weeks old were purchased from Jackson Laboratories (Bar Harbor, ME) and housed in Cedars-Sinai Medical Center's or the University of Michigan's high isolation animal rooms. Mice were allowed a minimum of 1 week to acclimate, after which 1 million PKH-26-labeled lung fibroblasts, 0.5 million to 1 million unlabeled biobanked explant cells, or 1:1 mixture of the two cell types ( 0.5 million per cell type; 1 million total cells) were injected intravenously into 8- to 12-week-old NSG mice. Mice receiving therapeutic treatments (days 35 to 63) were treated twice a week with anti-IL-13 or IgG antibodies (5 mg/ $\mathrm{kg}$ ) or daily with $5 \mathrm{mg} / \mathrm{kg}$ of AMD3100 intraperitoneally. Mice receiving IL-13-phosphatidylethanolamine (PE) received 200 ng of the protein intranasally twice a week therapeutically (days 35 to 63). Mice were monitored daily and were sacrificed if there was clear evidence of morbidity (weight loss of $>20 \%$, loss of fur, paralysis, and/or lack of responsiveness when 
handled). The remainder of the mice were sacrificed after 35 or 63 days or as indicated in Figures 1 and 2. Bronchoalveolar lavage fluid and serum were collected for protein analysis, the superior and middle lobes were collected for biochemical hydroxyproline quantification, the inferior lobe and spleens for flow cytometric analysis, the postcaval lobe for quantitative PCR analysis, and the left lung for histologic analysis.

\section{Histologic Analysis}

Left lung tissue was fixed in 10\% neutral buffered formalin solution for 24 hours and subsequently transferred into tissue cassettes and placed into a 70\% ethanol solution for a minimum of 24 hours. Tissues where then shipped to
McClinchey Histology Lab Inc. (Ann Arbor, MI) for paraffin embedding, sectioning, and Masson's Trichrome staining. Stained slides where examined using a Zeiss Axio Observer Z1 microscope and the Zeiss Zen 2012 software blue edition version 1.1.2.0 (Zeiss, Oberkochen, Germany).

\section{Hydroxyproline Assay}

Total lung hydroxyproline was analyzed as previously described, ${ }^{39}$ with a few modifications. Superior and middle lobes were surgically dissected and placed into $5-\mathrm{mL}$ sterile tubes and flash-frozen until all the samples had been collected. On the day of the assay, tissues were thawed and $500 \mu \mathrm{L}$ of distilled water was added to the tissues. Tissues

\section{A}

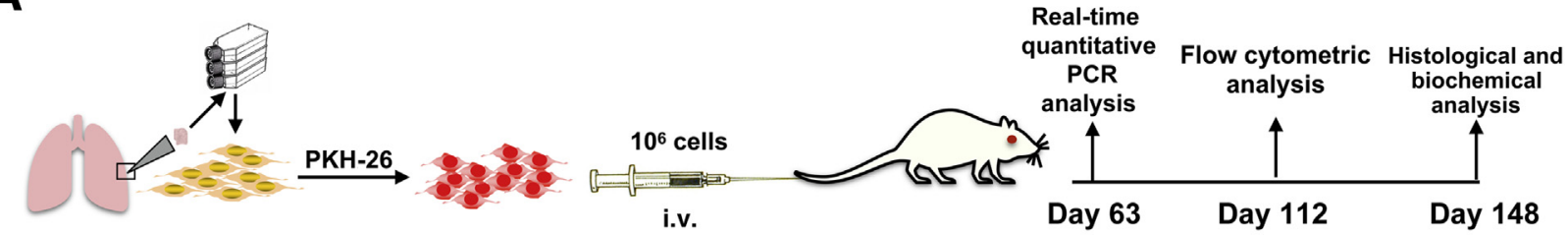

B

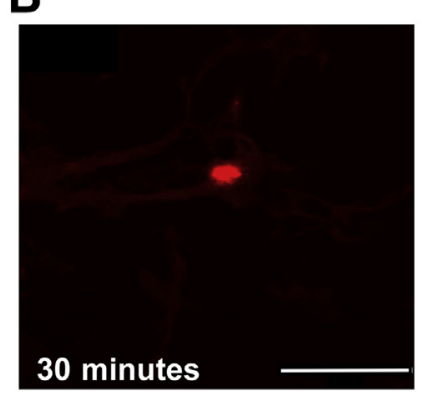

C

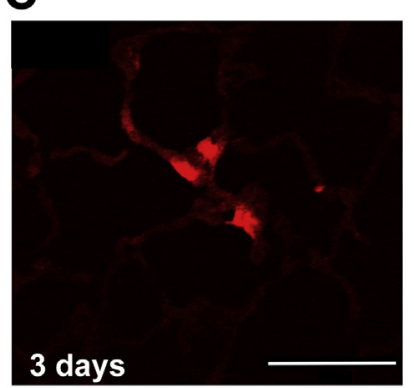

D

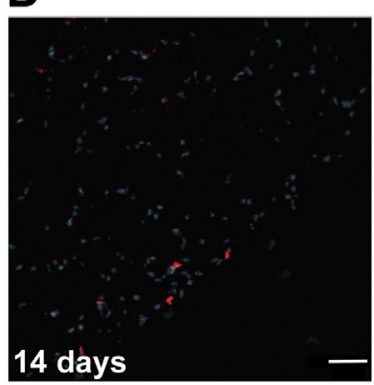

E

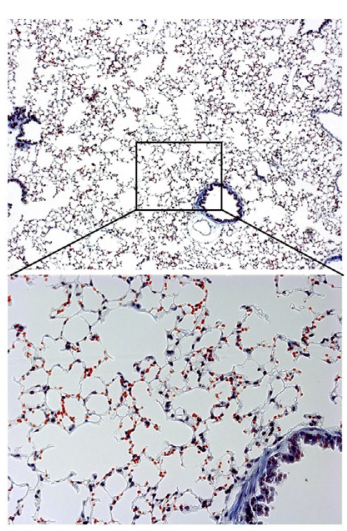

$\mathbf{F}$

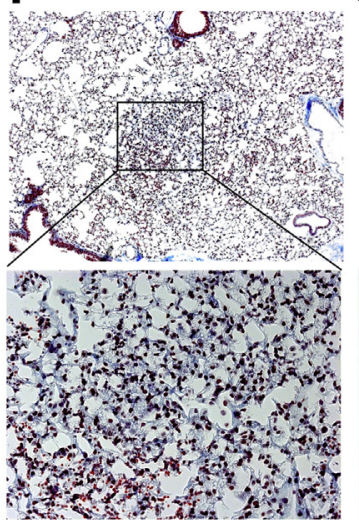

G

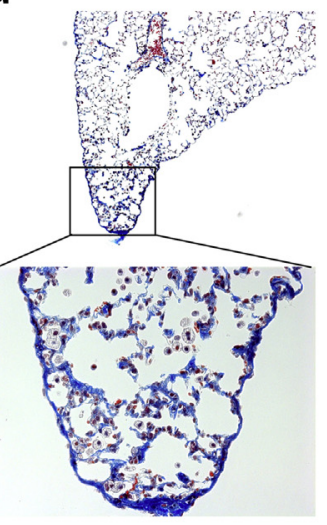

H

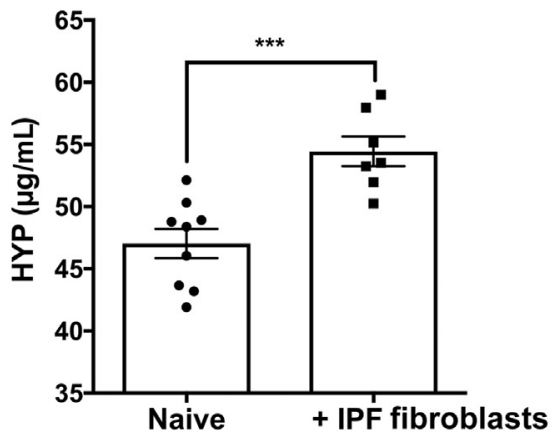

Figure 1 I.V. injection of idiopathic pulmonary fibrosis (IPF) lung fibroblasts induces interstitial lung remodeling in severe combined immunodeficiency (SCID) beige (bg) and nonobese diabetic SCID $\gamma$ (NSG) mice. A: Cultured IPF lung fibroblasts were injected intravenously into SCID/bg mice. Mice were sacrificed at various time points for immunofluorescence, transcriptomic, flow cytometric, histologic, and biochemical analysis. B-D: PKH-26 fluorescence in the pulmonary vasculature (B), interalveolar septum (C), and interstitium near the pleura (D) of SCID/bg mice 30 minutes (B), 3 days (C), and 14 days (D) after fibroblast administration. Shown are representative images from three experiments, where mice were administered with PKH-26 labeled lung fibroblasts. E-G: Masson's trichrome staining of naive (E) and IPF fibroblast-challenged NSG mouse lungs ( $\mathbf{F}$ and $\mathbf{G})$ at day 148 after injection. H: The mean hydroxyproline (HYP) content in naive and IPF fibroblast-challenged NSG mice at day 148 after fibroblast injection. $n=5$ per group in each experiment $(\mathbf{B}-\mathbf{D}) ; n=9(\mathbf{E}) ; n=7(\mathbf{F}$ and $\mathbf{G})$. $* * * P<0.001$ (unpaired parametric $t$-test). Scale bars $=50 \mu \mathrm{m}(\mathbf{B}-\mathbf{D})$. Original magnification: $\times 50$ (E-G, top row); $\times 200(\mathbf{E}-\mathbf{G}$, bottom row). 
A

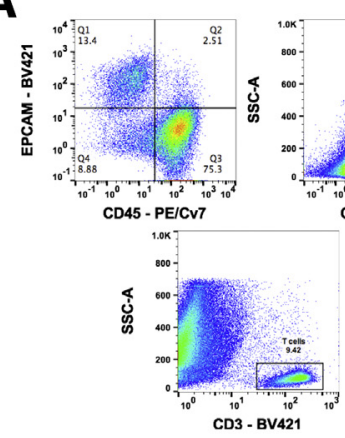

D

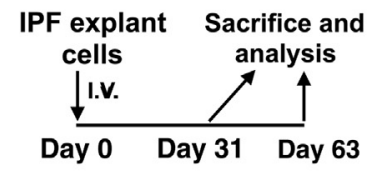

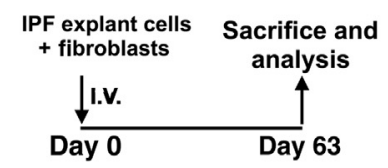

B

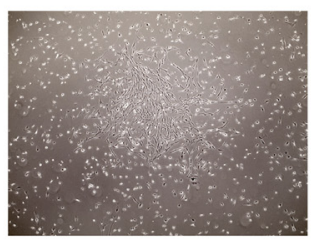

$\mathbf{F}$

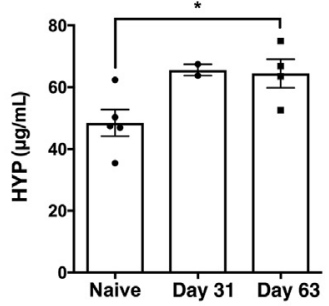

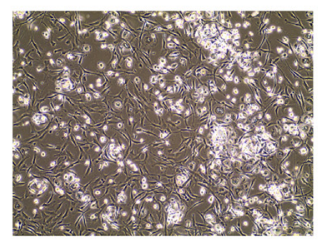

C

G

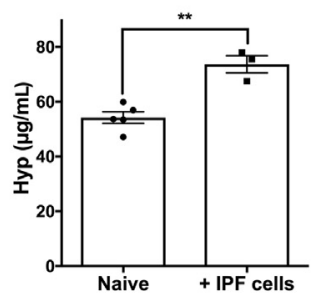

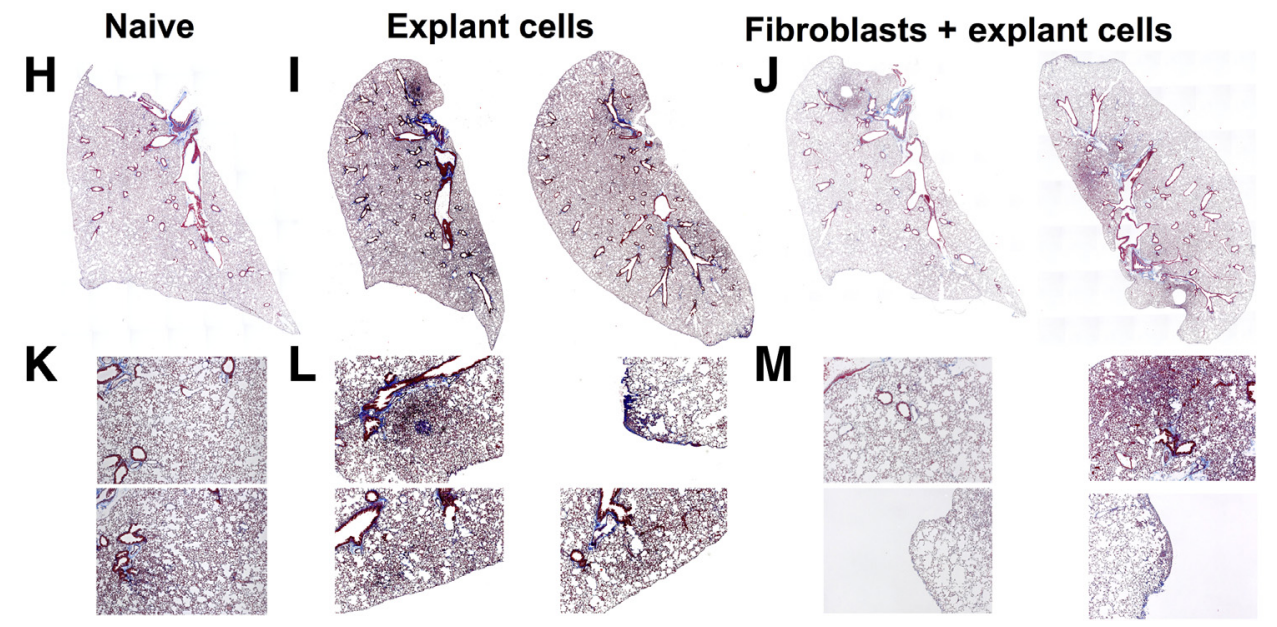

Figure 2 I.V. injection of cellular suspensions derived from idiopathic pulmonary fibrosis (IPF) lung explants induces robust subpleural and interstitial remodeling in nonobese diabetic severe combined immunodeficiency ILR2 $\gamma^{-/-}$(NSG) mice. A: Normal and IPF lung explants were mechanically dissociated, and the resulting cellular suspension was stained with various antibodies. Depicted are representative dot plots of cells stained with anti-CD45, EpCAM, CD31, NG2, SSEA4, CD3, CD19, and CD335 antibodies. B and C: Normal and IPF lung explant suspensions were cultured on cell culture-treated plastic dishes in serumcontaining medium. Depicted are representative images of fibroblast colonies observed after 1 to 2 weeks of explant cell culture. D and E: 0.5 to $1 \times 10^{6}$ freshly isolated or biobanked lung explant cells alone (D) or mixed 1:1 with isogenic lung fibroblast $\left(1 \times 10^{6}\right.$ total; E) were administered intravenously into NSG mice. Two mice were sacrificed after 31 days (D), and the remainder were sacrificed after 63 days. Lung tissues were isolated and collagen content was determined histologically and biochemically. $\mathbf{F}$ and $\mathbf{G}$ : The mean hydroxyproline (HYP) content in the superior and middle lobes in unchallenged naive and IPF lung explant (F) or IPF lung explant plus isogenic lung fibroblasts (G) challenged NSG mice at days 31 and 63 (F) or day 63 (G) after cellular injection. H-M: Representative Masson's trichrome staining of naive ( $\mathbf{H}$ and $\mathbf{K}$ ), IPF explant cell ( $\mathbf{I}$ and $\mathbf{L}$ ), and IPF explant plus isogenic lung fibroblast (J and $\mathbf{M})$ NSG lungs at day 63 after injection. $n=5$ unchallenged naive ( $\mathbf{F}$ and $\mathbf{G}) ; n=2-4$ IPF lung explant ( $\mathbf{F}$ and $\mathbf{G}) ; n=3$ IPF lung explant plus isogenic lung fibroblasts ( $\mathbf{F}$ and G). ${ }^{*} P<0.05,{ }^{*} P<0.01$ (unpaired parametric $t$-test). Original magnification: $\times 40(\mathbf{B}) ; \times 100(\mathbf{C}) ; \times 50(\mathbf{H}-\mathbf{M})$. APC, allophycocyanin; FITC, fluorescein isothiocyanate; $\mathrm{PE}$, phosphatidylethanolamine.

were homogenized using a microsample homogenizer (Pro Scientific, Oxford, CT), samples were transferred into Fisherbrand Borosilicate glass screw-capped tubes with a rubber liner (Thermo-Fisher Scientific, Waltham, MA), and $560 \mu \mathrm{L}$ of $12 \mathrm{~N}$ hydrochloride (Thermo-Fisher Scientific) was added to the homogenized tissues. Samples were capped, vortexed, placed into a preheated oven set to $120^{\circ} \mathrm{C}$, and incubated overnight. The next morning, samples were cooled, vortexed, and filtered through a $0.45-\mu \mathrm{m}$ syringe filter. Fifty microliters of the filtered samples were transferred into a 
1.5-mL microcentrifuge tube and evaporated on a heating block set to $100^{\circ} \mathrm{C}$ for 2 to 3 hours. While the samples were incubating, standards to generate a standard curve were prepared by diluting hydroxyl-L-proline (Sigma-Aldrich, St. Louis, MO) in acetate-citrate buffer [17 $\mathrm{g}$ of sodium hydroxide (Sigma-Aldrich), $36.2 \mathrm{~g}$ of sodium acetate (SigmaAldrich), $25 \mathrm{~g}$ of citric acid (Sigma-Aldrich), $6 \mathrm{~mL}$ of glacial acetic acid (Thermo-Fisher Scientific), and a final pH of 6 in a total of $500 \mathrm{~mL}$ of distilled water] into nine different concentrations ranging from 200 to $20 \mu \mathrm{g} / \mathrm{mL}$. After incubation, the desiccated sample pellets were resuspended in 50 $\mu \mathrm{L}$ of acetate citrate buffer, and biochemical quantification of hydroxyproline was performed as previously described. ${ }^{39}$

\section{RT-PCR Analysis}

Tissues were homogenized in Trizol reagent using a microsample homogenizer (Pro Scientific). RNA was extracted as recommended by the manufacturer, and $1 \mu \mathrm{g}$ of RNA was reverse transcribed into cDNA using Superscript II Reverse Transcriptase (Life Technology, Carlsbad, CA) as previously described. ${ }^{36}$ cDNA was subsequently loaded into a Taqman plate (Thermo-Fisher Scientific), and gene expression analysis were performed using predesigned primers and probes for human collal (Mm00801666_g1), ctgf (Mm00515790_g1), egfr (Mm00433023_m1), fbn1 (Mm00514908_m1), vegfa (Mm00437304_m1), wisp1 (Mm00457574_m1), cd44 (Mm01277164_m1), and tlr4 (Mm00445274_m1) (Thermo-Fisher Scientific). All Taqman analysis was performed using an Applied Biosystem's Viia 7 instrument (Thermo-Fisher Scientific). The results were then exported and normalized to 18s RNA expression (Thermo-Fisher Scientific), and fold-change values were calculated using DataAssist software version 3.01 (ThermoFisher Scientific).

\section{Statistical Analysis}

Unpaired parametric $t$-tests statistical analyses were performed using GraphPad Prism software version 7 (GraphPad Software Inc., La Jolla, CA).

\section{Study Approval}

Institutional review boards both at Cedars-Sinai Medical Center and the University of Michigan approved all experiments with primary human tissue. Informed consent was obtained from all patients before inclusion in the studies described herein. Cedars-Sinai Medical Center Department of Comparative Medicine and the University of Michigan Unit for Laboratory Animal Medicine approved all mouse studies described herein. All studies were performed in accordance with the relevant guidelines and regulations.

\section{Results}

\section{Modeling IPF in SCID Mice Using Human Lung Fibroblasts}

Given the idiopathic nature of IPF, this disease has been difficult to model in rodents. Our group described a humanized SCID/bg model of IPF approximately 10 years ago $^{34,36}$ initiated by a tail vein injection of $1 \times 10^{6} \mathrm{PKH}-$ 26-labeled IPF or nonspecific interstitial pneumonia (NSIP) lung fibroblasts into SCID/bg mice (Figure 1A). In this model, PKH-26-labeled fibroblasts were observed in the microvasculature of lung at 30 minutes after injection (Figure 1B), in interalveolar septum at day 3 (Figure 1C), and in the interstitum and near the pleural membrane at day 14 (Figure 1D) after injection. One challenge to this model is that these injected human fibroblasts are not readily detected afterward using fluorescent approaches in lung tissue sections (because of the dilution of the PKH-26 label in the proliferating cells) or flow cytometric approaches (because of the paucity of human fibroblast-specific markers). In this model, lung fibrosis was only observed after the injection of IPF or NSIP but not normal lung fibroblasts. ${ }^{34}$ Furthermore, this fibrotic remodeling of the lung was nonresolving, present as early as day 35 after fibroblast injection, and persistent up to 148 days after fibroblast administration, when interstitial (Figure 1F) and subpleural (Figure 1G) remodeling was readily observed in IPF lung fibroblast-xenografted (Figure 1, F and $\mathrm{G}$ ) but not naïve, nonxenografted, mouse lungs (Figure 1E). This finding was supported by a significant increase in hydroxyproline content in IPF fibroblast-xenografted relative to naïve, nonxenografted, mouse lungs (Figure $1 \mathrm{H}$ ). Together, the previously published $^{34}$ and current results demonstrate that the i.v. injection of cultured IPF but not normal fibroblasts into SCID/bg mice leads to remodeling in the mouse lung.

Neutralizing IL-13 Is Less Effective than Targeting IL-4 Receptor/IL-13 Receptor-Expressing Fibroblasts in Ameliorating the Lung Fibrosis in Humanized SCID/bg Mice

This SCID/bg IPF model has been previously used to determine the efficacy of various human- or mouse/ human-specific therapeutics, including anti-human CCL21 monoclonal antibody (mAb), anti-CXCL12 mAb, CC930, recombinant resistin, anti-human vascular endothelial growth factor $\mathrm{mAb}$, anti-human platelet-derived growth factor receptor mAbs, ${ }^{23}$ and anti-human IL-13 $\mathrm{mAb}$ (ie, tralokinumab). ${ }^{35}$ Regarding the last therapeutic approach in this list, AstraZeneca recently disclosed that neutralizing IL-13 via mAbs did not show efficacy in modulating disease progression in patients with IPF, ${ }^{40}$ unlike what we previously reported in humanized SCID/ bg mice. ${ }^{35}$ To address this discrepancy between our findings in humanized SCID mice and the clinical trial 
findings, we performed additional analysis in SCID/bg mice that received one of $\mathrm{IgG} 4$, anti-human IL-13 $\mathrm{mAb}$, or human IL-13 conjugated to Pseudomonas exotoxin (ie, Cintredekin Besudotox ${ }^{41}$ ) (Figure $3 \mathrm{~A}$ ) from days 35 to 63 after IPF fibroblast injection. IL-13-PE has antifibrotic effects in a variety of immunocompetent mouse models of pulmonary fibrosis because of its targeted killing of IL-4/ IL-13 receptor-expressing cells. ${ }^{41,42}$ As expected, IL13-PE-treated SCID/bg mice had a marked reduction in interstitial lung remodeling relative to saline-treated SCID/ bg mice, as assessed by Masson's trichrome histologic staining (Figure 3, B and C) and a significant reduction in hydroxyproline content (Figure 3D). Most strikingly, collal, egfr, fbn1, vegfa, wisp1, ctgf, cd44, and tlr4 transcripts were all increased in the anti-IL-13 $\mathrm{mAb}$ SCID/bg group compared with the IgG4-treated SCID/bg group (Figure 3E) but reduced after IL-13-PE treatment (Figure $3 \mathrm{E}$ ). These results suggest that targeting IL-13 might have enhanced various profibrotic/inflammatory transcripts, but targeting IL-4/IL-13 receptor-expressing cells using IL-13-PE inhibited this effect in this SCID/ bg model.

Modeling IPF in NSG Mice Using a Mixture of Immune and Structural Cells from IPF Lung Explants

Although the humanized SCID/bg model of fibrosis initiated with IPF lung fibroblasts described above continues to be
A

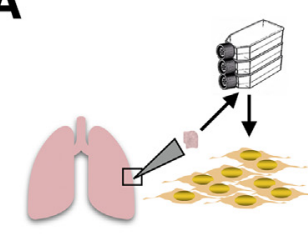

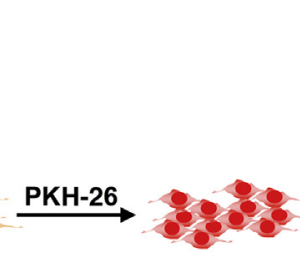

B

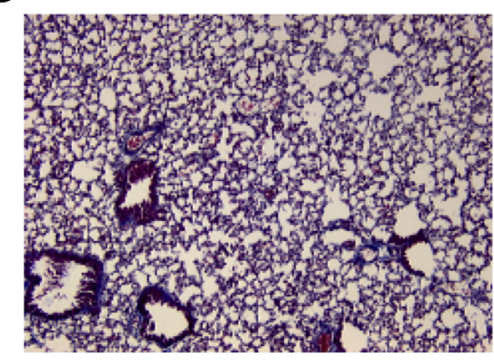

C

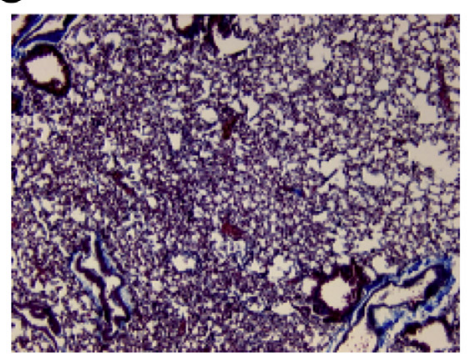

Treatment

(anti-IL-13 i.p.

twice per week)

(IL-13-PE intranasally

every 2 days, 200ng)

Day 35

Analysis

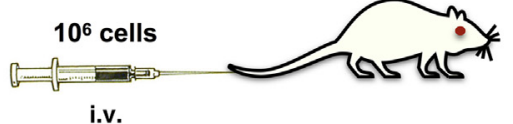

i.v.

D

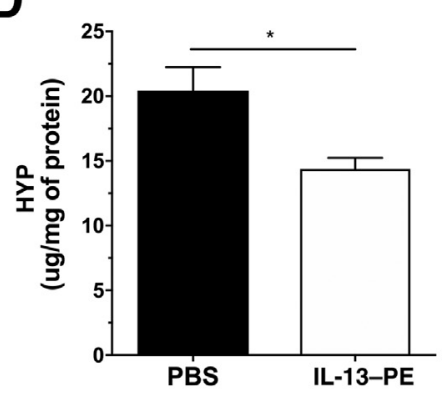

\section{$\mathbf{E}$}

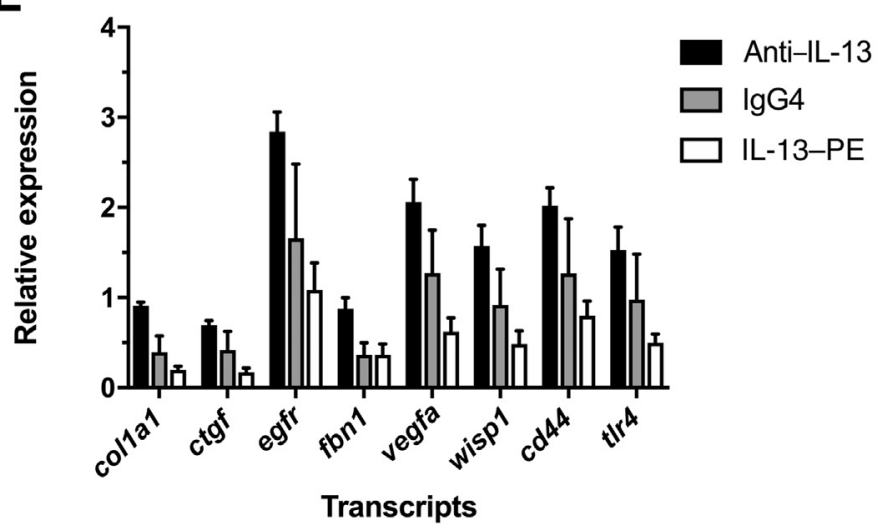

Figure 3 Targeting IL-13 but not IL-4 receptor/IL-13 receptor-positive cells induce the expression of proinflammatory and profibrotic mediators in a humanized severe combined immunodeficiency (SCID) idiopathic pulmonary fibrosis (IPF) model. A: Cultured normal or IPF lung fibroblasts were injected intravenously into SCID/beige mice. Thirty-five days after cellular administration, mice were treated intraperitoneally with anti-IL-13 monoclonal antibody (tralokinumab), IgG, or intranasally with $200 \mathrm{ng}$ IL-13-phosphatidylethanolamine (PE) or saline twice a week for 4 weeks. B and C: Representative Masson's trichrome staining of mouse lungs from IPF fibroblast-challenged mice, treated with IL-13-PE (B) or saline (C). D: The mean hydroxyproline (HYP) content in mouse lungs challenged with IPF fibroblasts after intranasal treatment with phosphate-buffered saline (PBS) or IL-13-PE. E: The mean expression of various transcripts in mouse lungs from mice challenged with IPF lung fibroblasts and treated with anti-IL-13 monoclonal antibody, IgG4, or IL-13-PE compared with saline-treated mice. Data are expressed as means \pm SEM. $n=3$ IL-13-PE (D); $n=5$ PBS (D); $n=5$ per group (E). * $P<0.05$ (unpaired parametric $t$-test). Original magnification, $\times 200$ (B and C). 
informative regarding the efficacy of fibroblast-directed therapeutic candidates, IPF is the culmination of the dysfunction or aberrant activation of a numerous other cell types, including epithelial and immune cells. Until recently, our efforts to explore the impact of other IPF cells in immunocompromised mice were impeded by their poor engraftment in the available SCID/bg strain. However, the advent of the NSG mouse allowed us to explore lung remodeling in this SCID strain, which exhibits superior engraftment of both human immune and nonimmune cell types (in addition to human fibroblasts). To this end, we have developed an additional iteration of a humanized NSG model of IPF via the i.v. injection of a fresh mixture of immune, epithelial, stromal, endothelial, pericytes, and SSEA4 ${ }^{+}$progenitor cells from explanted IPF lungs into NSG mice. Suspensions of explanted IPF lungs are generated via mechanical dissociation of lungs removed from patients at the time of transplant (Materials and Methods) and are composed of a mixture of several cell types, including $\mathrm{CD}_{4} 5^{+}\left(\mathrm{CD}^{+}, \mathrm{CD} 19^{+}\right.$, and $\mathrm{CD} 335^{+}$immune cells), $\mathrm{EpCAM}^{+}, \mathrm{CD} 31^{+}, \mathrm{NG}^{+}$, and $\mathrm{SSEA}^{+}$cells (Figure 2A). Although these cell suspensions are not cultured before injection into NSG mice, stromal cells/progenitors are present because the addition of the cell suspensions to plastic, tissue culture-treated dishes for 1 to 2 weeks in serum-containing medium (Dulbecco's modified Eagle's medium plus $15 \%$ fetal bovine serum plus L-glutamine and antibiotics) gives rise to fibroblast colonies (Figure 2, B and C). After the i.v. injection of 0.5 to $1 \times 10^{6}$ explant cells (Figure 2D) or $0.5 \times 10^{6}$ explant cells plus 0.5 $\times 10^{6}$ isogeneic fibroblasts (derived from cultured explant cells) (Figure 2E) into NSG mice, there was a significant increase in the hydroxyproline content in the lungs of NSG mice, particularly at day 63 after injection of explant cells (Figure 2F) or explant cells plus fibroblasts (Figure 2G). Lung remodeling was confirmed by Masson's trichrome staining, where there was clear evidence of subpleural and interstitial collagen deposition (blue staining) in both groups of NSG mice (Figure 2, I, J, L and M) compared with naïve NSG mice (Figure 2, $\mathrm{H}$ and $\mathrm{K}$ ). Together, these results demonstrated that the i.v. introduction of IPF lung explant cells induced significant lung remodeling in NSG mice.

\section{Emphysema-Like Histologic and Biochemical Phenotype Is Induced by Explant Cells from a Subset of Patients with IPF}

Modeling IPF using NSG mice has proven to be beneficial to assess profibrotic mechanisms elaborated by human cells in vivo. However, given the heterogeneity within patients with $\mathrm{IPF}^{43-45}$ and the presence of combined emphysema and fibrosis in a subset of the patients with pulmonary fibrosis, ${ }^{46-51}$ the phenotypes and therapeutic response observed in these humanized models can be variable. An example of this is the induction of an emphysema-like phenotype in NSG lungs after challenge with explant cells from approximately $30 \%$ of patients with IPF. Compared with naïve, nonhumanized NSG lungs (Figure 4, A and B), a subset of IPF explant cells did not induce interstitial remodeling in humanized NSG lungs (Figure 4, C and D); however, these cells induced a significant loss of hydroxyproline content in the humanized NSG lung tissues (Figure 4E). These results suggest that, consistent with the clinical phenotype of this disease, the cells of patients with IPF can induce variable

\section{Naive}

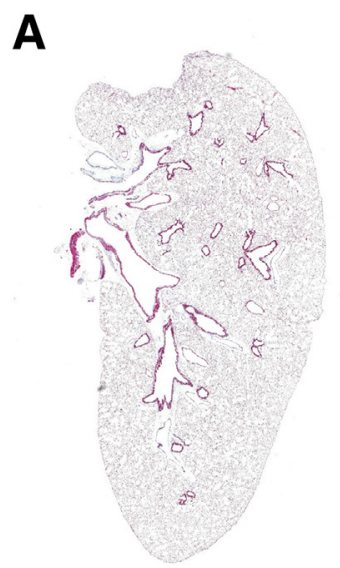

\section{+ IPF explant cells}

B

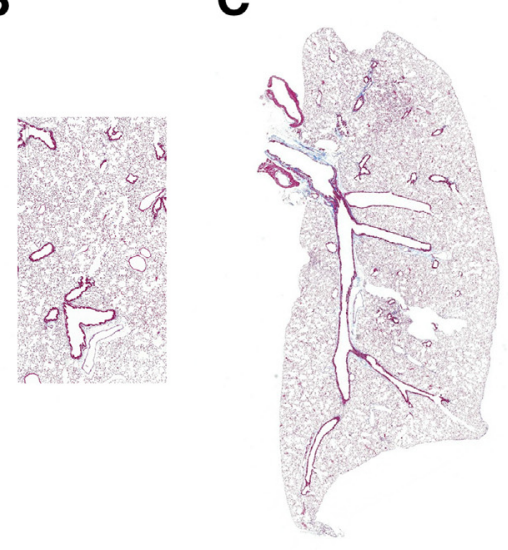

D
E

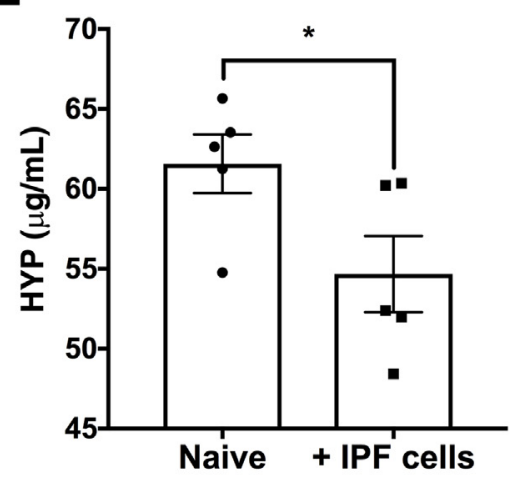

Figure 4 Explant cells from a subset of patients with idiopathic pulmonary fibrosis (IPF) induce enlargement of the alveoli and a net loss of hydroxyproline (HYP) content in humanized nonobese diabetic severe combined immunodeficiency IL2R $\gamma^{-/-}$(NSG) mice. One million freshly isolated or biobanked lung explant cells were administered intravenously into NSG mice. Sixty-three days after cellular administration, mice were sacrificed for histologic and biochemical analysis. A-D: Representative Masson's trichrome staining of naive NSG mouse lung (A and B) or lungs from NSG mice injected with IPF explant cells (C and D). E: The mean HYP content in naive and IPF explant cell-humanized NSG mouse lungs. $n=5$ per group $(\mathbf{A}-\mathbf{E})$. ${ }^{\star} P<0.05$ (unpaired parametric $t$-test). Original magnification: $\times 10(\mathbf{A}$ and $\mathbf{C}) ; \times 50(\mathbf{B}$ and $\mathbf{D})$. 
phenotypes in these humanized models of the disease. Thus, in studies designed to examine specific therapeutics using these models, patient selection and preassessment of the cells used is warranted before in vivo assessment.

\section{Validating the Efficacy of Therapeutically Targeting CXCR4 in NSG Mice Humanized with IPF Lung Explant Cells}

$\mathrm{C}-\mathrm{X}-\mathrm{C}$ chemokine receptor 4 (CXCR4) is an $\alpha$ chemokine receptor, known to bind to the $\mathrm{C}-\mathrm{X}-\mathrm{C}$ chemokine (CXCL12). Given its established role in cancer cell invasion ${ }^{52-56}$ and pulmonary fibrosis, ${ }^{57-61}$ the efficacy of AMD3100, a CXCR4-specific inhibitor, was assessed in NSG mice xenografted with lung explant cells isolated from patients with IPF who had rapid or slow progression at 1 year after diagnosis. ${ }^{36}$ Cells from both slow- and rapid-progressing IPF lungs induced lung remodeling in xenografted compared with nonxenografted mice based on both Masson's trichrome staining (Figure 5, A, B and D) and biochemical hydroxyproline quantification (Figure 5, F and G). Furthermore, therapeutic administration of AMD3100 (at $5 \mathrm{mg} / \mathrm{kg}$ by i.p. injection 5 days per week) from days 35 to 63 after IPF cell administration ameliorated lung remodeling induced by cells from patients with both slow- and rapid-progressing IPF. Both Masson's trichrome staining of NSG mouse lung tissue sections (Figure 5, A-E) and biochemical hydroxyproline quantification in the remodeled lungs (Figure 5, F and G) demonstrated the efficacy of targeting this chemokine receptor. Together, the results from this iteration of a humanized NSG model of pulmonary fibrosis are consistent with the findings in other mouse models of fibrosis, including humanized SCID/bg mice that received cultured fibroblasts, and demonstrate that CXCL12-CXCR4 interactions lead to remodeling in the mouse lung.

\section{Discussion}

Patients with IPF have a median survival of 3 to 5 years, and current therapeutic options slow but do not stop disease progression. During the past 10 years, our group has developed and tested various iterations of a model of lung fibrosis induced via the injection of IPF cells into SCID/bg or NSG mice. The first iteration of this model involved the i.v. introduction of cultured IPF or NSIP fibroblasts into SCID/bg mice, and key features of this model have been described herein and published elsewhere. ${ }^{34-36}$ Interestingly, although human normal, NSIP, and IPF fibroblasts are detected in other organs (including spleen, liver, kidney, and heart) in SCID/bg mice after i.v. injection, these injected human lung fibroblasts do not appear to be profibrotic outside the lungs of these mice, and only IPF and NSIP fibroblasts initiate pulmonary fibrosis. ${ }^{34}$ Although we have observed that certain IPF fibroblast lines reproducibly induce fibrosis in SCID/bg mice, the extent of the fibrotic responses induced by these cells can be variable among patients, and some IPF fibroblast lines less reliably induced a spontaneous fibrosis for reasons that we are now actively exploring. For example, fibroblasts from patients
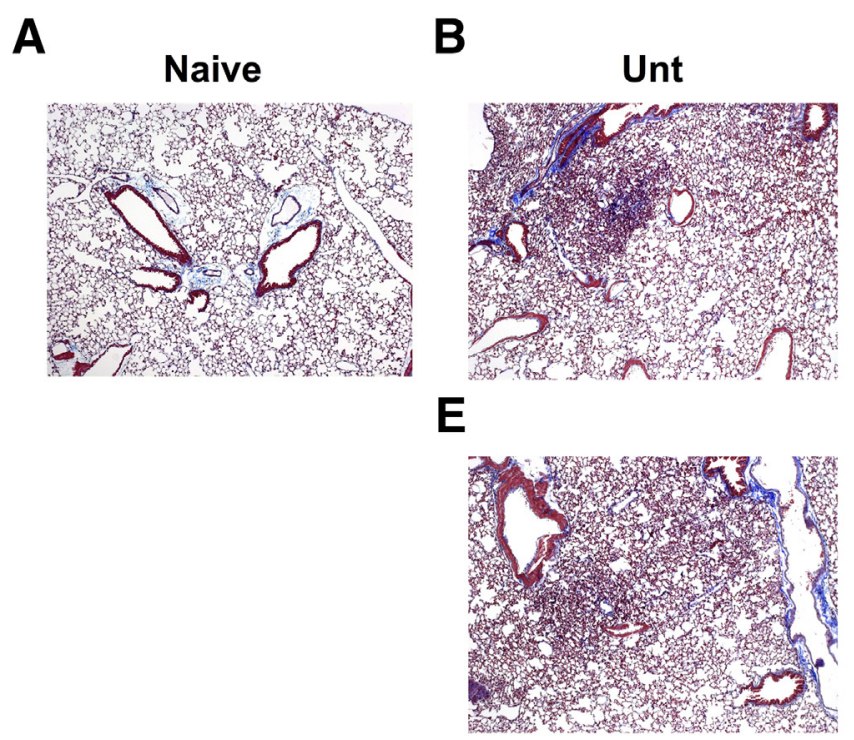

B

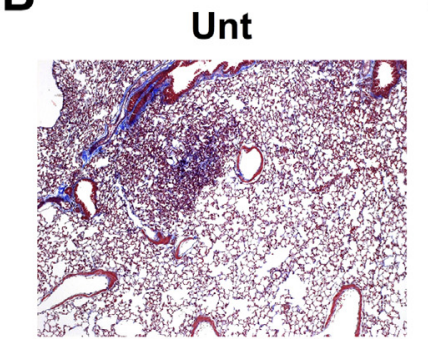

$\mathbf{F}$

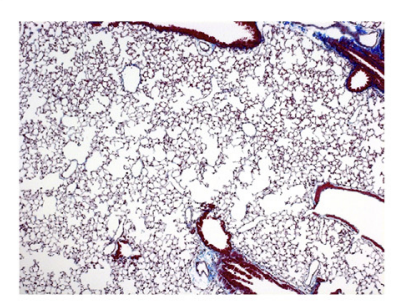

D
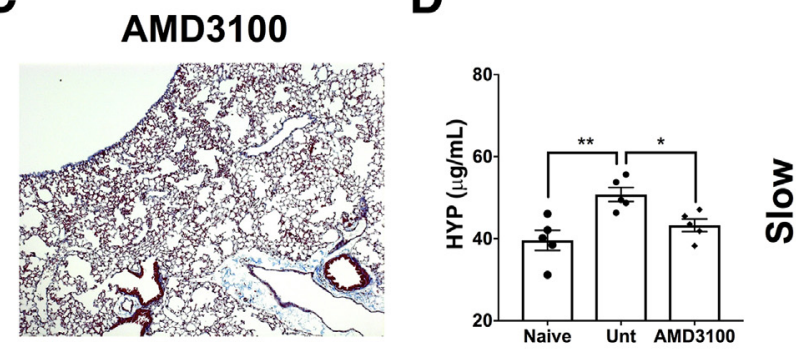

G

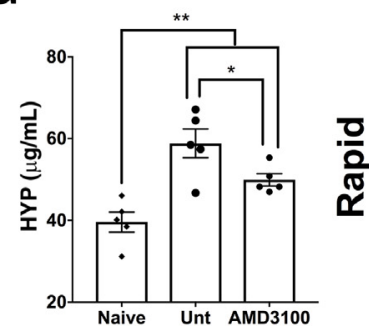

Figure 5 Targeting C-X-C chemokine receptor 4 (CXCR4) using AMD3100 ameliorates lung remodeling in nonobese diabetic severe combined immunodeficiency $\gamma$ (NSG) mice that were injected with lung explant cells isolated from a patient with rapidly or slowly progressing idiopathic pulmonary fibrosis (IPF). A total of $5 \times$ $10^{5}$ biobanked slowly or rapidly progressing IPF lung explant cells were injected intravenously into NSG mice. At day 35 after injection, one group of mice were injected daily with $5 \mathrm{mg} / \mathrm{kg}$ of AMD3100 ( 5 days per week) for an additional 4 weeks ( 63 days total), and the mice were then sacrificed for histologic and biochemical analysis. A-E: Representative Masson's trichrome staining of naive NSG mouse lung (A) or lungs from NSG mice injected with explant cells from a patient with slowly progressing IPF (B and $\mathbf{C}$ ) or from a patient with rapidly progressing IPF ( $\mathbf{D}$ and $\mathbf{E}$ ) untreated (Unt) (B and $\mathbf{E})$ or AMD3100 treated (C and $\mathbf{F})$ for 4 weeks. The mean hydroxyproline (HYP) content in naive and slowly progressing (D) or rapidly progressing (G) groups Unt or therapeutically treated with AMD3100. $n=5$ per group $(\mathbf{A}-\mathbf{G}) .{ }^{*} P<0.05,{ }^{*} P<0.01$ (unpaired parametric $t$-test). Original magnification: $\times 50(\mathbf{A}-\mathbf{C}, \mathbf{E}$, and $\mathbf{F})$. 
with rapidly progressing IPF induced a much more robust fibrotic phenotype when activated with hypomethylated DNA (or $\mathrm{CpG}$ ). ${ }^{36}$ Furthermore, the abundance of SSEA4 ${ }^{+}$progenitors in lung fibroblast cultures (which induce lung remodeling in NSG mice ${ }^{37}$ ) may also contribute to the variability observed among IPF lung fibroblast lines. Thus, in vitro assessment of the proliferative/senescence status (described in the next paragraph) and the abundance of invasive cells and SSEA4 $4^{+}$progenitor cells in lung fibroblast cultures is warranted before use in humanized NSG studies.

The role of senescence in interstitial lung fibrosis is controversial. Experimental evidence suggest that cellular senescence promotes lung fibrosis and disrepair, ${ }^{62-64}$ whereas alveolar type II epithelial cell senescence promotes interstitial lung remodeling. ${ }^{65}$ The role of fibroblast senescence in lung fibrosis remains controversial, in part because of the apparent fibroproliferation in IPF lungs, with studies reporting that global telomere dysfunction in mice leads to the lack of fibrotic lung remodeling in response to bleomycin injury ${ }^{66,67}$ and the lack of apparent fibrosis in mice with fibroblast-specific telomere dysfunction. ${ }^{68}$ However, there is evidence that fibroblast and myofibroblast senescence might indirectly promote lung fibrosis via the elaboration of inflammatory molecules and oxidative radicals leading to chronic disrepair in the already fibrotic lungs. ${ }^{69}$ In humanized NSG studies, there is a correlation between fibroblast senescence and the lack of IPF fibroblast - mediated interstitial lung remodeling in humanized mice. We hypothesize that this effect might be in part due to the reduced proliferation of these fibroblasts in vivo. Thus, careful attention to the proliferation/senescence status of IPF fibroblasts is required before their injection into immunocompromised mice.

Modeling this disease using lung fibroblasts alone in SCID/ bg mice continues to be informative regarding the direct impact of profibrotic pathways on these specialized cells in vivo. IL-13 is a Th2 cytokine that is thought to play a role in the several respiratory diseases, including asthma, ${ }^{70-73}$ lung fibrosis, ${ }^{25,35,41,42,74-76}$ and chronic obstructive pulmonary disease. ${ }^{77,78}$ Various mouse models of pulmonary fibrosis have shown that this cytokine might promote lung remodeling $35,39,41,42,74,79-82$; however, targeting this cytokine failed to modulate IPF disease progression in a phase 3 clinical trial. ${ }^{40}$ Targeting IL-13 in SCID/bg mice intravenously injected with IPF lung fibroblasts results in a marked reduction in histologic and cellular parameters of lung fibrosis. ${ }^{35}$ In assessing this therapeutic target, a fibroblast cell line that was responsive to this cytokine was selected in vitro before in vivo assessment in SCID/bg mice. Despite this selection criteria, further investigation of the targeting strategy revealed a major caveat: anti-IL-13 mAb-treated mice had a marked elevation of fibronectin transcripts and transcripts encoding for various proteins that play a role in lung fibrosis. Although the mechanisms that lead to elevated profibrotic transcripts and proteins in response to the anti-IL-13 mAb remain elusive, targeting IL-4 receptor/IL-13 receptor-expressing cells using IL-
13-PE is efficacious in ameliorating lung remodeling in immunocompetent mice challenged with various profibrotic stimuli, including bleomycin sulfate, parasite antigens, and fungal spores. ${ }^{41,42}$ IL-13-PE effectively and consistently reduced COLIAI, CTGF, EGFR, FBN1, VEGFA, WISPI, $C D 44$, and TLR4 transcripts compared with IgG4- or anti-IL13-treated humanized SCID/bg mice. These results suggest that neutralizing IL-13 rather than the elimination of IL13-responsive cells might lead to the eventual elevation of various profibrotic/inflammatory proteins and cytokines. Furthermore, one caveat in our studies that assessed this therapeutic target is that our model lacked effector immune cells (including lymphocytes). Given the immunomodulatory function of this cytokine, it is likely that targeting it might promote an inflammatory response that may negate potential therapeutic effects.

The advent of the NSG mouse provided us with a novel tool with which to explore the impact of both IPF nonimmune and immune cells in a humanized mouse system. These mice are optimal hosts for engrafted human cells because these mice lack ILR2R $\gamma$ expression, meaning these mice lack functional mouse natural killer, natural killer $\mathrm{T}$, and other innate immune cell types. This profound immunodeficiency ultimately leads to reduced rejection of engrafted human cells in the NSG mice. Accordingly, we have used mechanically dissociated cell suspensions (Materials and Methods) from IPF lung explants and introduced these cell mixtures via i.v. injection into NSG mice. Flow cytometric assessment of mechanically dissociated cells from 12 IPF lungs yielded a mean of $30 \%$ immune, 50\% epithelial, and 20\% $\mathrm{CD}^{-} 5^{-} \mathrm{EpCAM}^{-}$cells; however, assessment of similarly treated 10 normal lung samples yielded a mean of 55\% immune, 20\% epithelial, and $25 \% \mathrm{CD}^{-} 5^{-} \mathrm{EpCAM}^{-}$cells. Given these differences in the proportion of immune and epithelial cells between normal and IPF lung explant suspensions, controlling for the effects of IPF cells using normal donor samples in this model was not possible. Administration of IPF lung explant cells induced marked interstitial and subpleural lung remodeling and fibrosis in NSG mice at approximately day 30 after injection and more consistently at day 63 after injection. Furthermore, the addition of cultured fibroblasts to these mixtures did not appreciably further increase collagen content in the lungs of humanized NSG mice as assessed biochemically and histologically. Finally, there was no apparent expansion of $\mathrm{T}$ or $\mathrm{B}$ cells in the lungs or spleens or elevation in mouse tumor necrosis factor- $\alpha$, IL-12, or interferon- $\gamma$ in the bronchoalveolar lavage or the serum of NSG mice injected with IPF explant cells, suggesting that the lung remodeling observed in this model was not a result of graft-versus-host disease.

Various reports have suggested a role of CXCR4 (and CXCL12) in pulmonary fibrosis, where inhibiting this chemokine receptor ameliorated bleomycin-induced fibrosis in vivo and was antifibrotic in vitro. ${ }^{57-61} \mathrm{We}$ have confirmed the role of an established antifibrotic pathway (ie, CXCR4) in 
this humanized NSG model of IPF, where targeting CXCR4 using AMD3100, a specific CXCR4 antagonist, ameliorated interstitial lung remodeling in NSG mice injected with IPF lung explant cells derived from a patient with either slowly or a rapidly progressing IPF. However, one caveat in this study is the assumption that AMD3100 does not affect the baseline matrix in NSG mice and that it acts therapeutically on the human xenografted cells or murine cells responding to the human cells in the NSG lungs. AMD3100 has been observed to mobilize stem cells and leukocytes from the bone marrow in mice and clinically ${ }^{83}$ and to induce cardiotoxic adverse effects, ${ }^{84}$ rendering it problematic to target this pathway clinically and suggesting that it may induce xenograft cell-independent effects in NSG mice. Finally, in these studies, more hydroxyproline was observed in the lungs of NSG mice humanized with cells from a patient with rapidly progressive IPF compared with lungs from NSG mice humanized with cells derived from the lungs of a patient with slowly progressive IPF (Figure $4 \mathrm{~F}$ versus Figure $4 \mathrm{G}$ ). These differences may be due to different proportions of various cell types or intrinsic differences within the cells introduced into NSG mice. Future experiments with additional cells from patients with IPF are warranted to confirm these observations and to better assess the role of CXCR4-expressing cells in lung remodeling using this humanized model of pulmonary fibrosis. Thus, these results suggest that the i.v. administration of heterogeneous cellular suspensions from IPF lung explants induce lung remodeling in the lungs of NSG mice, and these mice are another useful model for testing putative antifibrotic therapeutics.

In summary, we detail IPF models that use either a single cell type (ie, cultured fibroblasts) or mixed cell types (ie, nonimmune and immune cells) to initiate and maintain lung remodeling in SCID/bg and NSG mice. We also describe how humanized SCID/bg and NSG models provide key insight into the efficacy of potential antifibrotic therapeutics. However, one major question remains: which one of these models might best represent the disease process observed in patients with IPF? Although each model of lung fibrosis has weaknesses and strengths, it is ultimately up to the end user to decide which modeling approach will be most beneficial to answer the hypothesis in question. The bleomycin model of lung fibrosis affords the end user a plethora of genetic approaches to intricately decipher mechanisms of lung fibrosis, whereas the single cell type humanized SCID/bg model affords the end user a reductionist approach to study mechanisms specifically elaborated by human lung fibroblasts to induce lung fibrosis in vivo. Both models may yield beneficial information that pertains to targeting specific pathways in the overall lung remodeling response or specifically in human lung fibroblasts. However, to assess the efficacy of a human-specific therapeutic in modulating lung fibrosis mediated by a mixture of immune and structural cells in IPF lungs, the mixed explant cell humanized NSG model might be more clinically relevant because this model is initiated by human IPF cells that have not been modified by cell culture conditions (ie, exposure to tissue culture plastic, fetal bovine serum, and antibiotic/antimycotic treatments) and involves the collective actions of several human cell types in the fibrotic process. Future studies are certainly warranted to decipher mechanisms involved in the lung fibrotic response elicited by various IPF cell types introduced into SCID/bg and NSG mice.

\section{Acknowledgments}

We thank the Cedars-Sinai Biobank and the flow cytometric core facilities at Cedars-Sinai Medical Center and University of Michigan for their help.

D.M.H. conceived, designed, and performed experiments, analyzed results, and wrote the manuscript; C.M.H. conceived and designed the experiments and wrote and edited the manuscript; M.S.E. performed experiments and edited the manuscript; A.L.C. performed experiments.

\section{Supplemental Data}

Supplemental material for this article can be found at https://doi.org/10.1016/j.ajpath.2017.12.020.

\section{References}

1. du Bois RM: Strategies for treating idiopathic pulmonary fibrosis. Nat Rev Drug Discov 2010, 9:129-140

2. King TE Jr, Bradford WZ, Castro-Bernardini S, Fagan EA, Glaspole I, Glassberg MK, Gorina E, Hopkins PM, Kardatzke D, Lancaster L, Lederer DJ, Nathan SD, Pereira CA, Sahn SA, Sussman R, Swigris JJ, Noble PW; ASCEND Study Group: A phase 3 trial of pirfenidone in patients with idiopathic pulmonary fibrosis. $\mathrm{N}$ Engl J Med 2014, 370:2083-2092

3. Richeldi L, du Bois RM, Raghu G, Azuma A, Brown KK, Costabel U, Cottin V, Flaherty KR, Hansell DM, Inoue Y, Kim DS, Kolb M, Nicholson AG, Noble PW, Selman M, Taniguchi H, Brun M, Le Maulf F, Girard M, Stowasser S, Schlenker-Herceg R, Disse B, Collard HR; Investigators IT: Efficacy and safety of nintedanib in idiopathic pulmonary fibrosis. N Engl J Med 2014, 370: 2071-2082

4. Fisher M, Nathan SD, Hill C, Marshall J, Dejonckheere F, Thuresson PO, Maher TM: Predicting life expectancy for pirfenidone in idiopathic pulmonary fibrosis. J Manag Care Spec Pharm 2017, 23 : S17-S24

5. Hecker L, Thannickal VJ: Nonresolving fibrotic disorders: idiopathic pulmonary fibrosis as a paradigm of impaired tissue regeneration. Am J Med Sci 2011, 341:431-434

6. King TE Jr, Pardo A, Selman M: Idiopathic pulmonary fibrosis Lancet 2011, 378:1949-1961

7. Xu Y, Mizuno T, Sridharan A, Du Y, Guo M, Tang J, WikenheiserBrokamp KA, Perl AT, Funari VA, Gokey JJ, Stripp BR, Whitsett JA: Single-cell RNA sequencing identifies diverse roles of epithelial cells in idiopathic pulmonary fibrosis. JCI Insight 2016, 1: e90558

8. Camelo A, Dunmore R, Sleeman MA, Clarke DL: The epithelium in idiopathic pulmonary fibrosis: breaking the barrier. Front Pharmacol 2014, 4:173

9. Smirnova NF, Schamberger AC, Nayakanti S, Hatz R, Behr J, Eickelberg O: Detection and quantification of epithelial progenitor cell populations in human healthy and IPF lungs. Respir Res 2016 , $17: 83$ 
10. Sakai N, Tager AM: Fibrosis of two: epithelial cell-fibroblast interactions in pulmonary fibrosis. Biochim Biophys Acta 2013, 1832: 911-921

11. Idiopathic Pulmonary Fibrosis Clinical Research Network; Raghu G, Anstrom KJ, King TE Jr, Lasky JA, Martinez FJ: Prednisone, azathioprine, and $\mathrm{N}$-acetylcysteine for pulmonary fibrosis. N Engl J Med 2012, 366:1968-1977

12. Huang Y, Ma SF, Espindola MS, Vij R, Oldham JM, Huffnagle GB, Erb-Downward JR, Flaherty KR, Moore BB, White ES, Zhou T, Li J, Lussier YA, Han MK, Kaminski N, Garcia JGN, Hogaboam CM, Martinez FJ, Noth I; COMET-IPF Investigators: Microbes are associated with host innate immune response in idiopathic pulmonary fibrosis. Am J Respir Crit Care Med 2017, 196:208-219

13. Molyneaux PL, Willis-Owen SAG, Cox MJ, James P, Cowman S, Loebinger M, Blanchard A, Edwards LM, Stock C, Daccord C, Renzoni EA, Wells AU, Moffatt MF, Cookson WOC, Maher TM: Host-microbial interactions in idiopathic pulmonary fibrosis. Am J Respir Crit Care Med 2017, 195:1640-1650

14. Margaritopoulos GA, Harari S, Caminati A, Antoniou KM: Smokingrelated idiopathic interstitial pneumonia: a review. Respirology 2016, 21:57-64

15. Iwai K, Mori T, Yamada N, Yamaguchi M, Hosoda Y: Idiopathic pulmonary fibrosis. Epidemiologic approaches to occupational exposure. Am J Respir Crit Care Med 1994, 150:670-675

16. Harris JM, Cullinan P, McDonald JC: Occupational distribution and geographic clustering of deaths certified to be cryptogenic fibrosing alveolitis in England and Wales. Chest 2001, 119:428-433

17. Taskar VS, Coultas DB: Is idiopathic pulmonary fibrosis an environmental disease? Proc Am Thorac Soc 2006, 3:293-298

18. Baumgartner KB, Samet JM, Coultas DB, Stidley CA, Hunt WC, Colby TV, Waldron JA: Occupational and environmental risk factors for idiopathic pulmonary fibrosis: a multicenter case-control study. Am J Epidemiol 2000, 152:307-315

19. Snider GL, Hayes JA, Korthy AL: Chronic interstitial pulmonary fibrosis produced in hamsters by endotracheal bleomycin: pathology and stereology. Am Rev Respir Dis 1978, 117:1099-1108

20. Snider GL, Celli BR, Goldstein RH, O’Brien JJ, Lucey EC: Chronic interstitial pulmonary fibrosis produced in hamsters by endotracheal bleomycin. Lung volumes, volume-pressure relations, carbon monoxide uptake, and arterial blood gas studied. Am Rev Respir Dis 1978, 117:289-297

21. Phan SH, Thrall RS, Williams C: Bleomycin-induced pulmonary fibrosis: effects of steroid on lung collagen metabolism. Am Rev Respir Dis 1981, 124:428-434

22. Degryse AL, Tanjore H, Xu XC, Polosukhin VV, Jones BR, McMahon FB, Gleaves LA, Blackwell TS, Lawson WE: Repetitive intratracheal bleomycin models several features of idiopathic pulmonary fibrosis. Am J Physiol Lung Cell Mol Physiol 2010, 299: L442-L452

23. B Moore B, Lawson WE, Oury TD, Sisson TH, Raghavendran K, Hogaboam CM: Animal models of fibrotic lung disease. Am J Respir Cell Mol Biol 2013, 49:167-179

24. Davis GS, Leslie KO, Hemenway DR: Silicosis in mice: effects of dose, time, and genetic strain. J Environ Pathol Toxicol Oncol 1998, 17:81-97

25. Kolodsick JE, Toews GB, Jakubzick C, Hogaboam C, Moore TA, McKenzie A, Wilke CA, Chrisman CJ, Moore BB: Protection from fluorescein isothiocyanate-induced fibrosis in IL-13-deficient, but not IL-4-deficient, mice results from impaired collagen synthesis by fibroblasts. J Immunol 2004, 172:4068-4076

26. Epperly MW, Guo H, Gretton JE, Greenberger JS: Bone marrow origin of myofibroblasts in irradiation pulmonary fibrosis. Am J Respir Cell Mol Biol 2003, 29:213-224

27. Haston CK, Travis EL: Murine susceptibility to radiation-induced pulmonary fibrosis is influenced by a genetic factor implicated in susceptibility to bleomycin-induced pulmonary fibrosis. Cancer Res 1997, 57:5286-5291
28. Lee CG, Homer RJ, Zhu Z, Lanone S, Wang X, Koteliansky V, Shipley JM, Gotwals P, Noble P, Chen Q, Senior RM, Elias JA: Interleukin-13 induces tissue fibrosis by selectively stimulating and activating transforming growth factor beta(1). J Exp Med 2001, 194:809-821

29. Kolb M, Margetts PJ, Anthony DC, Pitossi F, Gauldie J: Transient expression of IL-1beta induces acute lung injury and chronic repair leading to pulmonary fibrosis. J Clin Invest 2001, 107:1529-1536

30. Sime PJ, Marr RA, Gauldie D, Xing Z, Hewlett BR, Graham FL, Gauldie J: Transfer of tumor necrosis factor-alpha to rat lung induces severe pulmonary inflammation and patchy interstitial fibrogenesis with induction of transforming growth factor-beta1 and myofibroblasts. Am J Pathol 1998, 153:825-832

31. Sime PJ, Xing Z, Graham FL, Csaky KG, Gauldie J: Adenovectormediated gene transfer of active transforming growth factor-beta1 induces prolonged severe fibrosis in rat lung. J Clin Invest 1997, 100:768-776

32. Korfhagen TR, Swantz RJ, Wert SE, McCarty JM, Kerlakian CB, Glasser SW, Whitsett JA: Respiratory epithelial cell expression of human transforming growth factor-alpha induces lung fibrosis in transgenic mice. J Clin Invest 1994, 93:1691-1699

33. Hardie WD, Le Cras TD, Jiang K, Tichelaar JW, Azhar M, Korfhagen TR: Conditional expression of transforming growth factoralpha in adult mouse lung causes pulmonary fibrosis. Am J Physiol Lung Cell Mol Physiol 2004, 286:L741-L749

34. Pierce EM, Carpenter K, Jakubzick C, Kunkel SL, Flaherty KR, Martinez FJ, Hogaboam CM: Therapeutic targeting of CC ligand 21 or CC chemokine receptor 7 abrogates pulmonary fibrosis induced by the adoptive transfer of human pulmonary fibroblasts to immunodeficient mice. Am J Pathol 2007, 170:1152-1164

35. Murray LA, Zhang H, Oak SR, Coelho AL, Herath A, Flaherty KR, Lee J, Bell M, Knight DA, Martinez FJ, Sleeman MA, Herzog EL, Hogaboam CM: Targeting interleukin-13 with tralokinumab attenuates lung fibrosis and epithelial damage in a humanized SCID idiopathic pulmonary fibrosis model. Am J Respir Cell Mol Biol 2014, 50:985-994

36. Trujillo G, Meneghin A, Flaherty KR, Sholl LM, Myers JL, Kazerooni EA, Gross BH, Oak SR, Coelho AL, Evanoff H, Day E, Toews GB, Joshi AD, Schaller MA, Waters B, Jarai G, Westwick J, Kunkel SL, Martinez FJ, Hogaboam CM: TLR9 differentiates rapidly from slowly progressing forms of idiopathic pulmonary fibrosis. Sci Transl Med 2010, 2:57ra82

37. Xia H, Bodempudi V, Benyumov A, Hergert P, Tank D, Herrera J, Braziunas J, Larsson O, Parker M, Rossi D, Smith K, Peterson M, Limper A, Jessurun J, Connett J, Ingbar D, Phan S, Bitterman PB, Henke CA: Identification of a cell-of-origin for fibroblasts comprising the fibrotic reticulum in idiopathic pulmonary fibrosis. Am J Pathol 2014, 184:1369-1383

38. Moore BB, Hogaboam CM: Murine models of pulmonary fibrosis. Am J Physiol Lung Cell Mol Physiol 2008, 294:L152-L160

39. Hogaboam CM, Blease K, Mehrad B, Steinhauser ML, Standiford TJ, Kunkel SL, Lukacs NW: Chronic airway hyperreactivity, goblet cell hyperplasia, and peribronchial fibrosis during allergic airway disease induced by Aspergillus fumigatus. Am J Pathol 2000, 156:723-732

40. Parker JM, Glaspole IN, Lancaster LH, Haddad TJ, She D, Roseti SL, Fiening JP, Grant EP, Kell CM, Flaherty KR: A phase 2 randomized controlled study of tralokinumab in subjects with idiopathic pulmonary fibrosis. Am J Respir Crit Care Med 2018, 197:94-103

41. Jakubzick C, Choi ES, Joshi BH, Keane MP, Kunkel SL, Puri RK, Hogaboam CM: Therapeutic attenuation of pulmonary fibrosis via targeting of IL-4- and IL-13-responsive cells. J Immunol 2003, 171: 2684-2693

42. Jakubzick C, Kunkel SL, Puri RK, Hogaboam CM: Therapeutic targeting of IL-4- and IL-13-responsive cells in pulmonary fibrosis. Immunol Res 2004, 30:339-349

43. DePianto DJ, Chandriani S, Abbas AR, Jia G, N'Diaye EN, Caplazi P, Kauder SE, Biswas S, Karnik SK, Ha C, Modrusan Z, Matthay MA, Kukreja J, Collard HR, Egen JG, Wolters PJ, Arron JR: 
Heterogeneous gene expression signatures correspond to distinct lung pathologies and biomarkers of disease severity in idiopathic pulmonary fibrosis. Thorax 2015, 70:48-56

44. Noble PW, Barkauskas CE, Jiang D: Pulmonary fibrosis: patterns and perpetrators. J Clin Invest 2012, 122:2756-2762

45. Wang Y, Yella J, Chen J, McCormack FX, Madala SK, Jegga AG: Unsupervised gene expression analyses identify IPF-severity correlated signatures, associated genes and biomarkers. BMC Pulm Med 2017, 17:133

46. Oliva IB, Cortopassi F, Rochester CL, Rubinowitz AN: Combined pulmonary fibrosis and emphysema syndrome: a radiologic perspective. Monaldi Arch Chest Dis 2011, 75:220-234

47. Jankowich MD, Rounds SIS: Combined pulmonary fibrosis and emphysema syndrome: a review. Chest 2012, 141:222-231

48. Cottin V, Reix P, Khouatra C, Thivolet-Bejui F, Feldmann D, Cordier JF: Combined pulmonary fibrosis and emphysema syndrome associated with familial SFTPC mutation. Thorax 2011, 66:918-919

49. Zendah I, Gharsalli H, Khattab A, Ghedira H: The syndrome of combined pulmonary fibrosis and emphysema. Tanaffos 2011, 10: $59-62$

50. Cottin V, Nunes H, Mouthon L, Gamondes D, Lazor R, Hachulla E, Revel D, Valeyre D, Cordier JF; Groupe d'Etudes et de Recherche sur les Maladies "Orphelines" Pulmonaires: Combined pulmonary fibrosis and emphysema syndrome in connective tissue disease. Arthritis Rheum 2011, 63:295-304

51. Cottin V, Cordier JF: The syndrome of combined pulmonary fibrosis and emphysema. Chest 2009, 136:1-2

52. Li X, Ma Q, Xu Q, Liu H, Lei J, Duan W, Bhat K, Wang F, Wu E, Wang Z: SDF-1/CXCR4 signaling induces pancreatic cancer cell invasion and epithelial-mesenchymal transition in vitro through noncanonical activation of Hedgehog pathway. Cancer Lett 2012, 322: 169-176

53. Krook MA, Nicholls LA, Scannell CA, Chugh R, Thomas DG, Lawlor ER: Stress-induced CXCR4 promotes migration and invasion of ewing sarcoma. Mol Cancer Res 2014, 12:953-964

54. Zhu S, Hong J, Tripathi MK, Sehdev V, Belkhiri A, El-Rifai W: Regulation of CXCR4-mediated invasion by DARPP-32 in gastric cancer cells. Mol Cancer Res 2013, 11:86-94

55. Wang T, Mi Y, Pian L, Gao P, Xu H, Zheng Y, Xuan X: RNAi targeting CXCR4 inhibits proliferation and invasion of esophageal carcinoma cells. Diagn Pathol 2013, 8:104

56. do Carmo A, Patricio I, Cruz MT, Carvalheiro H, Oliveira CR, Lopes MC: CXCL12/CXCR4 promotes motility and proliferation of glioma cells. Cancer Biol Ther 2010, 9:56-65

57. Yuan A, Lee Y, Choi U, Moeckel G, Karihaloo A: Chemokine receptor Cxcr4 contributes to kidney fibrosis via multiple effectors. Am J Physiol Renal Physiol 2015, 308:F459-F472

58. Makino H, Aono Y, Azuma M, Kishi M, Yokota Y, Kinoshita K, Takezaki A, Kishi J, Kawano H, Ogawa H, Uehara H, Izumi K, Sone S, Nishioka Y: Antifibrotic effects of CXCR4 antagonist in bleomycin-induced pulmonary fibrosis in mice. J Med Invest 2013, 60:127-137

59. Song JS, Kang CM, Kang HH, Yoon HK, Kim YK, Kim KH, Moon HS, Park SH: Inhibitory effect of CXC chemokine receptor 4 antagonist AMD3100 on bleomycin induced murine pulmonary fibrosis. Exp Mol Med 2010, 42:465-472

60. Mehrad B, Burdick MD, Strieter RM: Fibrocyte CXCR4 regulation as a therapeutic target in pulmonary fibrosis. Int J Biochem Cell Biol 2009, 41:1708-1718

61. Xu J, Mora A, Shim H, Stecenko A, Brigham KL, Rojas M: Role of the SDF-1/CXCR4 axis in the pathogenesis of lung injury and fibrosis. Am J Respir Cell Mol Biol 2007, 37:291-299

62. Lehmann M, Korfei M, Mutze K, Klee S, Skronska-Wasek W, Alsafadi HN, Ota C, Costa R, Schiller HB, Lindner M, Wagner DE, Gunther A, Konigshoff M: Senolytic drugs target alveolar epithelial cell function and attenuate experimental lung fibrosis ex vivo. Eur Respir J 2017, 50. 1602367
63. Alvarez D, Cardenes N, Sellares J, Bueno M, Corey C, Hanumanthu VS, Peng Y, D'Cuhna H, Sembrat J, Nouraie M, Shanker S, Caufield C, Shiva S, Armanios M, Mora AL, Rojas M: IPF lung fibroblasts have a senescent phenotype. Am J Physiol Lung Cell Mol Physiol 2017, 313:L1164-L1173

64. Schafer MJ, White TA, Iijima K, Haak AJ, Ligresti G, Atkinson EJ, Oberg AL, Birch J, Salmonowicz H, Zhu Y, Mazula DL, Brooks RW, Fuhrmann-Stroissnigg H, Pirtskhalava T, Prakash YS, Tchkonia T, Robbins PD, Aubry MC, Passos JF, Kirkland JL, Tschumperlin DJ, Kita H, LeBrasseur NK: Cellular senescence mediates fibrotic pulmonary disease. Nat Commun 2017, 8:14532

65. Naikawadi RP, Disayabutr S, Mallavia B, Donne ML, Green G, La JL, Rock JR, Looney MR, Wolters PJ: Telomere dysfunction in alveolar epithelial cells causes lung remodeling and fibrosis. JCI Insight 2016, 1:e86704

66. Lee J, Reddy R, Barsky L, Scholes J, Chen H, Shi W, Driscoll B: Lung alveolar integrity is compromised by telomere shortening in telomerase-null mice. Am J Physiol Lung Cell Mol Physiol 2009, 296:L57-L70

67. Liu T, Ullenbruch M, Young Choi Y, Yu H, Ding L, Xaubet A, Pereda J, Feghali-Bostwick CA, Bitterman PB, Henke CA, Pardo A, Selman M, Phan SH: Telomerase and telomere length in pulmonary fibrosis. Am J Respir Cell Mol Biol 2013, 49:260-268

68. Naikawadi RP, Cheng N, Vogel SM, Qian F, Wu D, Malik AB, Ye RD: A critical role for phosphatidylinositol $(3,4,5)$-trisphosphatedependent Rac exchanger 1 in endothelial junction disruption and vascular hyperpermeability. Circ Res 2012, 111:1517-1527

69. Hecker L, Logsdon NJ, Kurundkar D, Kurundkar A, Bernard K, Hock T, Meldrum E, Sanders YY, Thannickal VJ: Reversal of persistent fibrosis in aging by targeting Nox4-Nrf2 redox imbalance. Sci Transl Med 2014, 6:231ra47

70. Blease K, Jakubzick C, Schuh JM, Joshi BH, Puri RK, Hogaboam CM: IL-13 fusion cytotoxin ameliorates chronic fungalinduced allergic airway disease in mice. J Immunol 2001, 167: 6583-6592

71. Blease K, Jakubzick C, Westwick J, Lukacs N, Kunkel SL, Hogaboam CM: Therapeutic effect of IL-13 immunoneutralization during chronic experimental fungal asthma. J Immunol 2001, 166: $5219-5224$

72. Ingram JL, Kraft M: IL-13 in asthma and allergic disease: asthma phenotypes and targeted therapies. J Allergy Clin Immunol 2012, 130:829-842; quiz 843-844

73. Corren J: Role of interleukin-13 in asthma. Curr Allergy Asthma Rep 2013, 13:415-420

74. Ferreira TP, de Arantes AC, do Nascimento CV, Olsen PC, Trentin PG, Rocco PR, Hogaboam CM, Puri RK, Martins MA, Silva PM: IL-13 immunotoxin accelerates resolution of lung pathological changes triggered by silica particles in mice. J Immunol 2013, 191:5220-5229

75. Chandriani S, DePianto DJ, N'Diaye EN, Abbas AR, Jackman J, Bevers J 3rd, Ramirez-Carrozzi V, Pappu R, Kauder SE, Toy K, Ha C, Modrusan Z, Wu LC, Collard HR, Wolters PJ, Egen JG, Arron JR: Endogenously expressed IL-13Ralpha2 attenuates IL-13mediated responses but does not activate signaling in human lung fibroblasts. J Immunol 2014, 193:111-119

76. Karo-Atar D, Bordowitz A, Wand O, Pasmanik-Chor M, Fernandez IE, Itan M, Frenkel R, Herbert DR, Finkelman FD, Eickelberg O, Munitz A: A protective role for IL-13 receptor alpha 1 in bleomycin-induced pulmonary injury and repair. Mucosal Immunol 2016, 9:240-253

77. van der Pouw Kraan TC, Kucukaycan M, Bakker AM, Baggen JM, van der Zee JS, Dentener MA, Wouters EF, Verweij CL: Chronic obstructive pulmonary disease is associated with the $-1055 \mathrm{IL}-13$ promoter polymorphism. Genes Immun 2002, 3:436-439

78. Lee JS, Rosengart MR, Kondragunta V, Zhang Y, McMurray J, Branch RA, Choi AM, Sciurba FC: Inverse association of plasma IL-13 and inflammatory chemokines with lung function 
impairment in stable COPD: a cross-sectional cohort study. Respir Res 2007, 8:64

79. Zhu Z, Homer RJ, Wang Z, Chen Q, Geba GP, Wang J, Zhang Y, Elias JA: Pulmonary expression of interleukin-13 causes inflammation, mucus hypersecretion, subepithelial fibrosis, physiologic abnormalities, and eotaxin production. J Clin Invest 1999, 103: 779-788

80. Blease K, Schuh JM, Jakubzick C, Lukacs NW, Kunkel SL, Joshi BH, Puri RK, Kaplan MH, Hogaboam CM: Stat6-deficient mice develop airway hyperresponsiveness and peribronchial fibrosis during chronic fungal asthma. Am J Pathol 2002, 160:481-490

81. Belperio JA, Dy M, Burdick MD, Xue YY, Li K, Elias JA, Keane MP: Interaction of IL-13 and C10 in the pathogenesis of bleomycin-induced pulmonary fibrosis. Am J Respir Cell Mol Biol 2002, 27:419-427
82. Keane MP, Gomperts BN, Weigt S, Xue YY, Burdick MD, Nakamura H, Zisman DA, Ardehali A, Saggar R, Lynch JP 3rd, Hogaboam C, Kunkel SL, Lukacs NW, Ross DJ, Grusby MJ, Strieter RM, Belperio JA: IL-13 is pivotal in the fibro-obliterative process of bronchiolitis obliterans syndrome. J Immunol 2007, 178: 511-519

83. Broxmeyer HE, Orschell CM, Clapp DW, Hangoc G, Cooper S, Plett PA, Liles WC, Li X, Graham-Evans B, Campbell TB, Calandra G, Bridger G, Dale DC, Srour EF: Rapid mobilization of murine and human hematopoietic stem and progenitor cells with AMD3100, a CXCR4 antagonist. J Exp Med 2005, 201:1307-1318

84. Dai S, Yuan F, Mu J, Li C, Chen N, Guo S, Kingery J, Prabhu SD, Bolli R, Rokosh G: Chronic AMD3100 antagonism of SDF-1alphaCXCR4 exacerbates cardiac dysfunction and remodeling after myocardial infarction. J Mol Cell Cardiol 2010, 49:587-597 